\title{
FROM THE DEVELOPMENTAL TO THE REGULATORY STATE: THE TRANSFORMATION OFTHE GOVERNMENT'S IMPACT ON THE BRAZILIAN ECONOMY.
}

\author{
Edmund Amann ${ }^{1}$ and Werner Baer ${ }^{2}$
}

$\mathrm{B}$ razil's large-scale privatisation programme in the 1990s presents the image of an economy in transition from state domination to one in which market forces prevail. The aim of this article is to show that such a characterisation of events masks a far more nuanced and complex picture in which the withering away of the state has been more apparent than real. Moreover, with the election of President Lula da Silva in October 2002, a profound shift in policy has occurred which beckons a resurgence of intervention and a recasting of the regulatory role of the state. To advance our argument, we shall mainly focus on the experience of the public utilities sector, in particular charting its experiences following privatisation.

To begin with, however, we set matters in a broader context briefly reviewing the evolution of state participation in the economy in the period stretching from the 1930 s to the late 1970s, stressing its influence in shaping the industrialisation process. In addition, we shall review the transformation of state enterprises from being a mainly positive influence on the Brazilian economy to becoming increasing dysfunctional. This will be followed by a brief overview of the extent of the privatisation process of the $1990 \mathrm{~s}$, and the resulting change of the role of the state in the country's economy, that is, from being a direct participant to being mainly a regulatory agent. Our particular concern in this regard will be to offer a preliminary assessment of the success of the state's new "regulatory approach" focusing on the experiences of the electricity and telecommunications sectors. The paper concludes by examining the likely development of utilities regulation now that President Lula da Silva's government is in place. 


\section{THE PARTICIPANT STATE: $1930-1980$}

Beginning in the 1930s and accelerating in the post World War II period the state enterprise sector became dominant in public utilities, heavy industry, the exploitation of natural resources and the financial sector. It was complementary to the private domestic and multinational, sectors, that is, each ownership sector specialised in specific sectors in the economy where it had the greatest comparative advantage. By the 1970s a large proportion of the steel industry (approximately $70 \%$ of capacity) was in the hands of state enterprises. Similarly state enterprises were heavily involved in the exploitation of natural resources, as was the case with Petrobras (Petroleum and various derivative industries) and Vale do Rio Doce (mineral exploitation $)^{3}$. In addition to these areas, public sector ownership was widespread in the field of public utilities, railroad transportation, ports and the banking and financial sector (which includes the gigantic development bank - BNDES, and commercial banks owned either by the federal or state governments).

The importance of the state can also be gauged by the following facts: a) a 1974 survey of the 5113 largest incorporated firms showed that over 39\% of assets belonged to SOEs, while these same firms were responsible for $16 \%$ of the value of sales; b) a 1985 survey of the 8094 largest firms revealed that the share of net assets of state enterprises amounted to $48 \%$, while the share of these enterprises in total sales totalled $28.1 \% .{ }^{4}$ The state also had an extremely powerful position in the financial sector.

The loans of the BNDES, together with other federal and state development banks, and official savings banks amounted to about $50 \%$ of gross capital formation in 1980s. The state also had a considerable influence in the commercial banking sector. For instance in 1985 the Banco do Brasil (the federally owned commercial bank) held $24 \%$ of all funds on deposit in Brazil's 50 largest commercial banks including some commercial banks owned by the state governments. Finally, at the beginning of the 1980s, the national development bank, the national housing bank (now extinct), the Bank of the Northeast and various development banks of individual states, provided more than $70 \%$ of the loans devoted to investment purposes. What was the impact of this substantial presence of the state in the Brazilian economy and was it necessarily harmful to the interests of the private sector?

It has been argued that for a long period of time this large-scale presence of the state in the economy was beneficial to both the domestic and foreign-owned private sectors. ${ }^{5}$ State firms provided relatively cheap inputs to the private sector (steel, electric power etc.). The state was also the major source of finance for both public and private investment activities. In fact, there was a remarkable growth of savings in the 1960s and 70s which was due to the government sector. The latter created and administered many forced saving funds through various social security levies. For instance, in 1974 64\% of Brazil's savings were due to publicly 
administered social security funds; by 1980 this had risen to over $70 \%$. All these factors went some way to contributing to the accelerated growth which Brazil enjoyed between 1950 and 1980. However beneficial the impacts regarding growth, the hefty presence of the state failed to address the worsening pattern of income distribution. ${ }^{6}$

\section{THE DECADENCE OF STATE ENTERPRISES}

Already, by the late 1970s a number of weaknesses inherent in the extensive presence of state enterprises had become apparent. The main features of the decadence of state enterprises were the following: a) the use of state enterprises as macroeconomic policy instruments, for instance forcing state enterprises to restrain their prices and tariffs they charged for their products in order to repress inflationary pressures. This did not halt inflation but caused large deficits in the affected enterprises, undermining their efficient operations and forcing the state to subsidise the losses incurred, which in turn, worsened the government deficit; b) the political pressure to over-employ in SOEs and to increasing hire individuals with personal connections to executive positions; c) the increasing number of cases of corruption resulting from the quasimonopoly position of state firms in certain sectors; d) the use of public enterprises to borrow more on the international market than they needed in order to provide the inflow of foreign exchange in order to cope with a deteriorating balance of payments. This placed many SOEs in a precarious financial position. ${ }^{7}$

\section{THE PRIVATISATION DRIVE OF THE I990}

In the 1980s the combination of the debt crisis, the fiscal crisis and bouts of hyperinflation forced Brazil to adopt a set of neo-liberal policies, one of whose main features was privatisation. The pressure to adopt privatisation policies came not only from within, but also from the demands of Brazil's major external creditors, most especially the multilateral organisations, the IMF and the World Bank. ${ }^{8}$

\section{THE PRIVATISATION EXPERIENCE}

Starting timidly in the late 1980s but accelerating markedly after 1994, Brazil engaged in one of the world's largest privatisation programmes. At first privatisation was concentrated in the steel and petrochemicals sectors, later embracing such state firms as the airplane manufacturer Embraer. From 1994 on the privatisation programme expanded rapidly, as it now included public utilities, such as telecommunications, electricity distribution, railroads, ports and some of the major high- 
ways. At first foreign participation was limited. After a number of constitutional amendments which allowed foreign firms to participate in public utilities, the involvement of foreign capital in the privatisation process increased dramatically. By 2002, receipts for privatisation amounted to US\$105.3bn. Of this, foreign participation totalled US\$ $42.1 \mathrm{bn}$ and on a sectoral basis privatisation of public utilities amounted to $63 \% .^{9}$

It is important to note that a substantial source of domestic participation in the privatisation auctions was constituted by the public sector using the resources of forced savings schemes. In this regard, the role of public sector pension schemes should be highlighted. For instance, in the case of the steel industry - among the earliest privatisations - the Banco do Brasil pension fund, Previ, was a key player. By 1997 it had acquired a substantial (23.9\%) stake in Acesita (a special steels company) which, in turn, owned important stakes in two other steel enterprises, Indústrias Villares and Aços Villares (De Paula, 1998). Within the same industry, a consortium of other public sector pension funds had managed to acquire a substantial stake in Belgo Mineira, a key enterprise in the speciality steels market. Of course, the role of the public sector pension funds in the privatisation process extended to well beyond the steel sector. In the case of Previ ${ }^{10}$, it can be shown that by the end of 2002, the fund had acquired major stakes across a range of key privatised companies. ${ }^{11}$

\section{THE ROLE OF THE STATE AS A REgulator}

One notable feature of Brazil's privatisation has been the fact that public utility privatisation has been carried out through the granting of concessions rather than a permanent transfer of assets. The winner of the concession contract would be running a facility for a limited period of time (usually 20-25 years) at the end of which the assets would revert to the state unless a new concession would be granted either to the old firm or a newcomer after an appropriate auction. During the concession period, the concession contract would be in force. It would include provisions for rate or tariff readjustments, investment obligations for both maintenance and upgrading the relevant facilities etc. For instance in the telecommunications sector, strict targets have been set for increasing provision of fixed and cellular lines, while service quality is also monitored and enforced. ${ }^{12}$

The administration of the concession contract would be in the hands of special regulatory institutions (e.g. ANATEL; ANEEL) and in some cases government ministries. As one commentator noted the introduction of these agencies established "an array of sectoral regulatory-normative federal agencies that... have changed not only the procedures but indeed the culture of Brazilian public sector management primarily in the area of infrastructure. Previously line ministries or public enterprises 
under their jurisdiction have carried out not only policy-making functions but also economic alterations..."13

An additional aspect of privatisation through concessions was that the BNDES development bank helped to finance both domestic and foreign bidders in the auction process.

\section{THE REGULATORY STATE AND ITS ECONOMIC INFLUENCE}

Since public utilities privatisation through the concessions model had the heaviest weight in the privatisation process, regulation has become one of the most important channels through which the state can influence economic activity. ${ }^{14}$ Of the state's various regulatory responsibilities one of the most significant concerns the setting of tariffs. In formulating policy in this regard the state has had to balance the influence of competing constituencies. In the period of rapid privatisation, the state in an effort to attract bidders to its concession auctions prioritised the interests of investors, raising tariffs sharply in order to raise the rate of return and thus attract the maximum number of bidders. ${ }^{15}$

As a result of the regulator's lenient policies towards the new concessionaires, profitability of public utilities increased dramatically. For instance, in the case of electricity generation, from being negative average profitability rose to $1.8 \%$ as a percentage of turnover in 1996 to $4.3 \%$ in $1999 .{ }^{16}$ For the electricity distribution sector, too, the initial years post-privatisation proved a favourable period: between 1995 and 1999 average profitability increased from 4.3\% to 5.9\%, having been negative for much of the first half of the decade.

An important consequence of privatisation was that the concessionaires were required to substantially upgrade the facilities they administered under the concession contract. This was often made easier by the government through generous loans made to the concessionaires via the BNDES. In the case of the electricity sector, between 1995 and 2000 no less than $43.8 \%$ of total investments carried out by the newly privatised utility enterprises was financed using funds from the BNDES. Such funding resulted in a surge in fixed capital formation: between 1994 and 1999 installed capacity in the generating sector leapt from $54.1 \mathrm{GW}$ to $64.0 \mathrm{GW} .{ }^{17}$ The railroad transportation system has also been realising a quantum leap in investment following its privatisation through the launch of concessions. Once again the BNDES is proving a key player in financing rises in fixed capital formation: between 2000 and 2004 the Bank has committed itself to funding $47 \%$ of the projected rise in network capacity. ${ }^{18}$

In the case of the $9945 \mathrm{~km}$ of privatised federal and state highways the BNDES has also proven an active participant in the financing of infrastructural improvements. Since the launch of the concessions, the Bank has provided funding amounting to $31 \%$ of total investments in highway upgrading. 


\section{Political CHANGe AND ITS REgulatory imPlicATIONS}

By 2002 the harmonious relationship between the government and the concessionaires began to unwind. There have been a number of reasons for this. For instance, the high interest rate policies adopted in order to defend the exchange rate contributed to low economic growth and to an increase in the burden of debt incurred by the concessionaires. This was reinforced by the devaluation of the Real in January 1999 and the continued depreciation of the currency throughout up to the final quarter of 2002. The resulting rise in the cost of the debt of many concessionaires made them demand generous increases in their tariffs.

However, as early as 1998 the attitude of the government was already becoming less favourable to the concessionaires and more sympathetic to the needs of the lowincome population and to other hard-pressed users of public utilities. For example, in the case of highway concessions, the protests of associations of truck drivers in various states forced the government to reduce tolls. ${ }^{19}$ These reductions, in turn were contested by a number of concessionaires, who went to court claiming that by reducing tolls the government had violated the concession contracts. ${ }^{20}$ This demonstrates an early example of the pressures from different groups to which regulators were subject. In the case of the telecommunications sector, the election of the Lula administration appears to herald similar downward pressure on tariffs. At present (2003) telecommunications enterprises are seeking to maintain in place arrangements by which tariffs are adjusted in line with general price inflation. However, according to the Minister for Communications, Miro Teixeira, this regulatory approach is unlikely to survive for long with the "elimination of rate indexation and the promotion of increased competition." 21

In 2003, downward pressures on tariffs had resulted in a potential change of the ownership landscape as there were signs that some concessionaires were seriously thinking of abandoning their concession contracts, resulting in a process of renationalisation.

Another key regulatory issue faced by the concessionaires in the wake of privatisation has had less to do with the level of tariffs per se than with uncertainty over their future path and the transparency which attaches to their setting and enforcement. In this regard, the performance of some of the regulatory agencies has been more investor-friendly than others. In the case of the electrical energy sector, for example, the regulator, ANEEL, has come under consistent criticism for the opacity, complexity and inconsistency of its management of tariff setting. For Landau (2002, p.5) ANEEL comes in for criticism "for its failure to adopt clear, unequivocal and rational rules on tarification. This factor has contributed significantly to insufficient private investment in power generation (because investors did not know the relative prices of inputs and outputs of generation plant, leading to shortages..).” 


\section{ACHIEVEMENTS AND FAILURES OF REGULATION: THE CONTRASTING FORTUNES OF ELECTRICITY AND TELECOMMUNICATIONS}

Of course, it should be recognised that the post privatisation period in Brazil has been associated with regulatory achievements as well as failures. The case of telecommunications offers a sharp contrast with that of electrical energy. The telecommunications regulator, ANATEL, has succeeded in presiding over a surge in both capacity and in competition whether in the fields of fixed line or mobile services. ${ }^{22}$ However, the experience of the electrical energy sector has proven far less favourable, a conclusion underlined by the power shortages and outages that plagued Brazil in 2001 2. What factors can help account for this apparent contrast in fortunes?

In first place, it is important to recognise the fundamentally different technological drivers affecting Brazilian electrical and telecommunications utilities. Although both classic "network industries", the telecommunications sector has in the past 10 years witnessed a far more rapidly moving technological frontier than electricity. One consequence of this is that the unit cost of furnishing capacity in telecommunications has rapidly fallen as technologies such as fibre-optic transmission and digital exchanges have been diffused. At the same time, the introduction of cellular telecommunications technology (in particular high-capacity digital networks) has greatly enhanced the capability of utilities to provide voice and data services to consumers and, for the first time, to offer a real alternative to fixed line networks. The effects of these fundamental technological facts (which are all too often ignored in the regulatory debate in Brazil) have been, above and beyond the ability to deliver rapidly increased capacity, to challenge the very nature of telecommunications as a classic natural monopoly.

In the case of electricity, by contrast, the pace of technological change has been far more restricted while Brazil has remained overwhelmingly reliant on hydro-electric power. Whatever regulatory regime might have been applied would have had to face this reality and to recognise the relative supply inelasticity inherent in it. Nevertheless, it is undeniable that difficulties of the electricity sector in particular the arrival of the power supply crisis - could have been avoided had additional (especially thermal and long-distance transmission) ${ }^{23}$ capacity been available. The fact that events unfolded differently, and that sector performance was so much poorer than telecommunications, must therefore be viewed in part as a regulatory artefact.

There are a number of reasons that help explain why this was the case. First, as Goldstein \& Pires (2001) point out, there is the question of timing. Unlike its counterpart in telecommunications, the electricity regulator, ANEEL, was not established at the outset of privatisation, rather coming into being once the process was underway. According to Goldstein \& Pires (2001, p.21) this led to its "legitimacy in dispute settlement and arbitration (being) contested”. According to Salgado (2003) 
these problems were compounded by the continuing co-existence of public sector enterprises (such as Chesf and Furnas) with private sector ones, a situation quite unlike that in telecommunications. The lingering role of the state as owner as well as its newly established one as regulator not unsurprisingly led to conflicts of interest. The sense that there were privileged players within the generating sector is one of a number of factors which help to explain why private sector investment in it has proven so restricted. More generally, Salgado (2003) notes that an inconsistency of important contractual rules, especially between generators and distributors across the sector, has made ANEEL's task very complex and has certainly retarded efforts to stimulate the entry of new investors.

Aside from uncertainty and complexity regarding the regulatory framework in electricity, it is also worth noting that, in at least partial contrast to telecommunications, the problem is one of regulatory governance and institutional development itself. As Goldstein and Pires (2001, p.21) put it: "as most of ANEEL's top management is formed by former DNAEE 24 officials, the signal given to private investors is that the crux of the regulatory game still concerns technical, legal and operational issues, and not the creation of the economic incentives necessary to create a really competitive market”. In addition, it should be pointed out that one key aspect of ANEEL's external institutional relations, that with the oil and water regulators (ANP and ANA), has not been coordinated in an efficient or effective manner. Thus, critical issues for the electricity generating sector such as the development of water and gas resources have not been addressed in an inter-departmentally "joined-up" or integrated fashion.

\section{The government of President Lula da Silva, Public utilities AND THE FUTURE EVOLUTION OF THE REGULATORY STATE}

From the foregoing, the appropriate conclusion would seem for the electricity regulator, to emulate in some sense the experience of the telecommunications sector ${ }^{25}$, and to develop investor-friendly regulatory regimes which have as their core a focus on transparency, predictability and, above all, a commitment to setting tariffs designed to stimulate growth in capacity. ${ }^{26}$

While this appears valid within a permanently privatised public utilities setting, it implies that the socio-political preferences of society will not change and that, therefore, it is possible for the regulatory agencies to be permanently inclined towards favouring the private investor. We have, however shown in this article that in a democratic regime there may be substantial swings in the mood and preferences of society. If, for any reason, this mood swings in the direction of more populist policies, that is, placing equity above the need to entice investors, the possibility of more lasting guarantees facing investors will not be possible. 
With the election of President Lula da Silva in October 2002 the regulatory agencies established under President Cardoso have come under acute pressure. According to a recent article in the Washington Times, President da Silva is seeking to curb the regulators' powers after having accused these agencies of having overseen excessively investor-friendly pricing regimes. In particular, President da Silva was quoted as stating that "(the regulators) are procuring the political power of Brazil. They've created a wall between themselves and the government." The article further states that the new president and his team have been studying the country's regulators, targeting them for changes which are said to benefit certain sectors more than the population in general. Among the issues of contention between the government and the regulators is the linkage of price rises for intermediate inputs such as steel and ethanol to movements in the US Dollar. The article further states that the new government has put the brakes on recent attempts to increase energy rates by more than $40 \%$ over the next four years.

Finally, a Senator Aloizio Mercadante, a confidant of the president, and the government's leader in the Senate said that "there are serious problems with the agencies, from the area of tariffs to that of regulation. The government has lost the ability to regulate important sectors such as utilities." Another politician close to the president, Congressman Roberto Jefferson stated that "we are certain that the regulators (are acting) above the law." "They're treated like a parallel power. I think the performance of these agencies is really an abuse."27

Changes in the political atmosphere alluded to above could also manifest themselves in the government's policy regarding the appointment of key personnel to the regulatory agencies. ${ }^{28}$ Landau (2002, p.8-9) has observed that up to the end of the Cardoso administration the government gave preference in its nominations to "expertise over partisan allegiance or the exchange of political favours, but the vagaries of politics in the future may intrude on this very sensitive process. The outstanding example of an agency governed by personalities of acknowledged stature is ANATEL, whose resolutions tends to be politically neutral whereas ANEEL, where nominations are made on the basis of political rather than technical criteria, has often produced resolutions that result in controversy, to say the least, and that are disputed (often in court) by both concession-holders and consumer groups."

Another perceptive observation relating to the inevitably political nature of the regulatory mission emerges from a recent international report. ${ }^{29}$ The report draws attention to the fact that "it is one thing for countries to make a policy decision to create an independent regulatory agency, and quite another to empower the agency to act independently and effectively... Inevitably (regulatory agencies) are the products of political, social and legal conditions that exist at fixed points in time, in each country... regulatory approaches and policies change, and agencies change with them" (International Telecommunications Union, 2001 p.1). 
Some might even doubt that investor-friendly regulatory policies will attract a substantial amount of private investment. As we have indicated, a large proportion of the financing of public utilities in Brazil was supplied by the BNDES using public money. Were the financially parlous state of the utilities sector to result in its progressive re-nationalisation then, in the absence of investor friendly regulatory policies, much needed increases in investment could only be implemented through either direct subsidies of consumers or through direct public sector capital investment. In other words, it is ironic that whether the administration of public utilities remains within the private sector or reverts to direct government control, then in either case the resources of the state will always be required to sustain investment programmes. Of course, one might take the view that, whatever the role of the state in providing capital, these resources might be used more efficiently used by privately administered entities.

At the beginning of the 21 st Century it would seem that the major influence of the state on economic activities is through its regulatory agencies and through the development bank. Through regulation it influences the country's electric power supply, its telecommunications system, its rail and road transportation network, its oil exploration and production sector (both through the still publicly owned Petrobras and the regulation of the activities of foreign oil prospectors). In addition, the state development bank is still the major source of investment funds. Through these instruments - both as a regulator and as financier - the state continues to exercise a major influence over the development of these sectors. More specifically, given the existence of thin capital markets - which necessitate borrowing at subsidised interest rates - and regulated prices, two of the most important dimensions of the economic environment faced by "privatised" enterprises are set by the state.

Above and beyond any regulatory or financing role, it should be remembered that the state has not entirely relinquished its position as the channel through which savings are accumulated (forced savings through pension funds) and then directed at favoured sectors. We have shown among the most favoured sectors have been the privatised utilities and such industries as steel.

With a depressed domestic market, and the financially parlous state of many multinational utilities groups (especially in telecommunications) many enterprises in the Brazilian utilities sector have been experiencing liquidity problems which the state is increasingly less willing to address through favourable tariff adjustments. This may lead many of the concessionaires to abandon their contracts, in essence leading to a "re nationalisation" of the utility.

An interesting example of the difficult current (2003) state of the utilities sector is provided by the case of Eletropaulo, the São Paulo electricity distributor whose concession was obtained by the US group AES in 1998. AES has run into difficulties with its Brazilian subsidiary as tariffs and consequently revenues have failed to rise in line 
with the enterprise's debt payment obligations to its creditors, most especially the BNDES. Owing the BNDES US\$1.13bn of which US\$ 600 million is past due, AES has found itself - temporarily at least - unable to continue with its repayments, triggering heated negotiations between itself and the Bank. The regulatory and financial conflict between AES and organs of the Brazilian state has now become something of a test case regarding public policy response to the deteriorating condition of the utilities sector. Mindful of the implications for other foreign investors, the US State Department has become involved with the US Ambassador to Brazil attempting to intercede. ${ }^{30}$

AES/Eletropaulo is not the only example of a foreign-owned utility in financial difficulties. In the case of the French-owned EDF, its Rio de Janeiro electricity distributor, LIGHT, owes more than US\$ 125 million to a consortium of domestic and foreign banks. ${ }^{31}$ In addition, the Minas Gerais - based distributor SEB/CEMIG (also partially-owned by AES) is overdue on some US\$ 87 million debt payment to the BNDES.

While in many regards, the liberalisation of the Brazilian telecommunications sector has proved more successful than in the case of electricity, the sector may nevertheless face serious problems. In particular, some enterprises will struggle to extract themselves from the trap of heavy indebtedness and lack of liquidity. These problems initially surfaced following the depreciation of the Real in early 1999. Since then, a number of service providers have been struggling to meet their debt obligations, faced with a mismatch between foreign currency denominated debts and local currency denominated revenue streams. To make matters worse, revenues have been constrained by a combination of price regulation and the failure of market demand to expand to the extent originally anticipated. In the most recent casualty of these unfavourable conditions, the São Paulo cellular service operator BCP was taken over by its creditors in April 2003, forcing the exit of a major US shareholder, Bell South.

In order to prevent future recurrences of such cases, the authorities would need to ensure that tariff alterations appropriately reflected the evolving cost base of telecommunications enterprises. On this score, the outlook for the sector is not especially favourable. In June 2003, hot on the heels of criticism from President da Silva himself, a series of legal injunctions overturned Anatel-agreed tariff increases nationwide. ${ }^{32}$ More troublingly still for Anatel, a draft presidential decree released in May 2003 mandated the handing back of much responsibility for the oversight of the telecommunications sector from the regulatory agency to the Ministry for Communications. In particular, the decree requires that Anatel be stripped of its decision-making functions in terms of tariff setting and the establishment of service obligation rules. So long as uncertainty continues to surround the regulation of the telecommunications sector, it is difficult to envisage a renewed wave of investment of the type experienced in the 1990s.

Perhaps the firmest statement to date of the Lula government's intent regarding the regulation of public utilities came at the end of 2003 with the announcement of 
a Presidential decree establishing a New Model for the electricity sector (IPEA, 2003). The measures contained in the decree reflect two key policy precepts that have emerged in the government's other pronouncements on public utilities; that regulation should be increasingly "repatriated" to the ministries from the agencies and that the thrust of policy should aim at delivering low tariffs over the longer term in order to realise social objectives.

Pursuant to these guiding principles, the New Model mandates that future tenders for generation projects be evaluated not on the basis of the most modest use of public funds but on their ability to deliver the lowest tariffs (ibid. p.26). In addition, decisions over the award of such tenders will be made by the Ministry of Mines and Energy (MME) and not, as hitherto, by ANEEL. This represents a real stripping away of power from the regulator and could presage yet further centralisation of regulatory functions by the MME. The other key provision of the Model strengthens the sanctions against distributors who experience difficulties in making payments to their suppliers. Since the state remains a key player in the generation market while the private sector predominates to a much greater extent in the distribution sector, this represents a clear manipulation of regulatory policy in the direct interest of the public sector.

The current direction of policy and the not unrelated sickly state of many privatelyowned utility providers clearly raises an important issue for the government: can it any longer attract the bidding of new concessionaires, and in order to do this, would it be obliged to offer more generous tariff conditions? If the re-nationalised enterprises should remain in the hands of the public sector, would the state be in a position to run a deficit-generating public utility? If the latter, the implication may be that there would be a decline in the rate of return accruing to the investments of the "forced savers" administered by the BNDES. In the past such a reduction in the rate of return may have been feasible against the backdrop of a relatively young population. Nowadays, however, with an ageing population relying increasingly on savings through the social security system, there would be less scope for such financing arrangements.

Even in the non-public utility sectors which were privatised in the 1990s but whose new owners were also heavily indebted to the development bank, what would happen if due to difficult economic conditions, that is, lower growth and higher interest rates, the owners of these firms defaulted? In this eventuality it appears probable that their debt to the BNDES would have to be converted into ownership shares. Thus, a form of re-nationalisation would occur.

\section{CONCLUSION}

In this article we have shown that Brazil's economy in the aftermath of privatisation has not become as fully exposed to market forces as one might have expected. All of the important public utilities sectors are subject to substantial regulation and a large 
proportion of all productive sectors remain dependent on the state for investment financing. We would not wish to pretend that the post privatisation period has witnessed no meaningful alteration in the scope of state intervention in the productive sector. In particular it should be emphasised that privatised enterprises now have much greater control over their internal functioning, their cost base and, most important of all the size and composition of their labour force which is no longer subject to political interference. ${ }^{33}$

However, we have shown that a more populist stance in regulating public utilities and the precariousness of the debtors of the development bank (due to interest and exchange rate movements) may augur a period of progressive re-nationalisation and, at the same time, could jeopardise the security of the forced savings of the public. It is thus more than clear that the functioning of the Brazilian economy will not be subject solely to market forces but will continue to be strongly influenced by the actions of the state.

\section{NOTES}

1 School of Economic Studies, University of Manchester

2 University of Illinois at Urbana-Champaign

3 For details see Baer (2001) Ch. 12 and Amann, De Paula and Ferraz (2002) and also Baer (1969)

4 Baer (2001)

5 See Evans (1979), Amann (2000), Baer (2001)

6 Wells (1976) Werneck (1986)

7 Baer (2001, pp. 283-284)

8 Castelar Pinheiro (1999)

9 BNDES Privatização no Brasil (2003)

10 Previ had by the end of the 1990s acquired a $13.8 \%$ stake in CSN, Brazil's largest and oldes steel company (Amann, De Paula \& Ferraz, 2002)

11 For instance, among Previ's R\$13.4bn in total equity holdings in December 2002 the following privatised companies featured prominently: Acesita R\$39M; Brasil Telecom R\$143M; Eletropaulo R\$22M; Embraer R $\$ 852 \mathrm{M}$; CVRD R\$307M (Source: Previ Annual Report 2002)

$12 \operatorname{BNDES}(2000$, p.9) 
13 Landau, Georges 'The regulatory-normative framework in Brazil', Policy Papers on the Americas, Vol. XIII, Study 2 April 2002 p. 2 CSIS, Washington D.C.

14 For a comprehensive review of the rise of the regulatory state in alternative national contexts see Glaeser and Shleifer (2003)

15 In the city of Rio de Janeiro, for example, while the consumer price index rose by $189.7 \%$ between August 1994 and February 2000, the price index for public services rose by $264.7 \%$.

$16 \operatorname{BNDES}(2000 \mathrm{~b})$

17 ibid.

\section{$18 \operatorname{BNDES}(2000 \mathrm{c})$}

19 In 1998 truck driver protests resulted in a 50\% reduction in tolls; in 1999 tolls were reduced between 20 and $28 \%$ and in July 1999 there was a brief national truckers' strike demanding a toll reduction.

20 BNDES Seminário de Privatização, November 2000

21 Brazil Focus David Fleischer, 24th February 2003

22 International Telecommunications Union (2001) Another comprehensive review of the accomplishments in the telecommunications area can be found in a chapter by Siqueira in Lamounier \& Figueiredo (eds.) 2002 pp. 215 240. The same volume also contains a chapter on the accomplishments in the transport sector written by De Toledo pp. 241-292

23 Much long distance high-voltage transmission capacity remains in the hands of the state. Efforts to boost private investment in this sector have been particularly hampered by regulatory uncertainty and constant changes in stance by ANEEL (Goldstein \& Pires, 2001)

24 The government department responsible for sector regulation prior to privatisation.

25 We do not of course wish to pretend that the telecommunications sector has been without its problems: as will be seen recent anaemic growth in revenues allied to foreign currency linked debt have taken their toll and are prompting a process of corporate restructuring.

26 José Claudio Linhares Pires, Fabio Giambiagi and André Franco Sales, 'As perspectives do setor eletrico após o racionamento', Revista do BNDES, 18, Dezembro de 2002 pp. 163-203

27 (Article by Bradley Brooks 'Brazil may curb regulators' powers', The Washington Times February 20th 2003)

28 This is also emphasised in a general survey of Latin America's electricity sector: see Fischer \& Serra

(2000, pp.188-189), Spiller \& Cardilli (1997) and Spiller \& Viana-Martorell (1996)

29 International Telecommunications Union, Effective Regulation Case Study: Brazil, 2001

30 Estado de São Paulo, 12th and 13th March 2003; Jornal do Brasil, 12th March 2003

31 VALOR, 2 Julho de 2003, p. B 1.

32 A $41.7 \%$ readjustment of rates which had been authorised by Anatel was suspended by the Court of Justice of Rio de Janeiro Jornal do Brasil, June 30th 2003 p. A7.

33 In the case of the railroad sector, for example, employment since privatisation has declined substantially. Employment in that part of the railroad network formerly controlled by the RFFSA has fallen from 28,639 in 1996 to 12,807 in 2000 (Ministério de Transportes, 2000). 


\section{BIBLIOGRAPHY}

AMANN, E (2000) Economic Liberalisation and Industrial Performance in Brazil, Oxford and New York: Oxford University Press

AMANN, E, De Paula, G. \& Ferraz, J. (2002) 'Ownership structures in the postprivatised Brazilian steel industry: complexity, instability and the lingering role of the state' mimeo University of Manchester

BAER, W (1969) The Development of the Brazilian Steel Industry, Nashville Tennessee: Vanderbilt University Press BAER, W (2001) The Brazilian Economy, Growth and Development, 5th edition, Westport Connecticut: Praeger BNDES (2000) Telecommunicações: Cenário Pós-Privatização no Brasil, Rio de Janeiro: BNDES

BNDES (2000b) O Setor Elétrico Pós-Privatização no Brasil, Rio de Janeiro: BNDES

BNDES (2000c) As Concessões Ferroviárias, Rio de Janeiro: BNDES

BNDES (2003) Privatizações no Brasil, Rio de Janeiro: BNDES

BROOKS, Bradley (2003) 'Brazil may curb regulators' powers', Washington Times, February 20th

CASTELAR PINHEIRO (1999) 'Privatização no Brasil: Por quê? Até onde? Até quando?' in F. Giambiagi \& M.

Mesquita Moreira (eds.) A Economia Brasileira nos Anos 90, Rio de Janeiro: BNDES

Estado de São Paulo (2003) March 12th and 13th

EVANS, P (1979) Dependent Development:The Alliance of Multinational, State and Local Capital in Brazil, Princeton NJ: Princeton University Press

FISCHER, R. \& Serra, P (2000) 'Regulating the electricity sector in Latin America', Economia, Vol. 1, No.1, Fall pp. 155-198

FLEISCHER, D (2003) Brazil Focus, February $24^{\text {th }}$

GLAESER, E.L.\& Shleifer, A (2003) 'The rise of the regulatory state,' Journal of Economic Literature, Vol. XLI No.2, June pp.401-425

GOLDSTEIN, A. \& Pires, J.C.P (2001) Brazilian Regulatory Agencies: Early Appraisal and Looming Challenges, mimeo International Telecommunications Union (2001) Effective Regulation - Case Study: Brazil, Geneva: International Telecommunications Union

24 IPEA (2003) Boletim de Politica Industrial, Dezembro

Jornal do Brasil (2003) March 12th

LAMOUNIER, B \& Figueiredo, R (eds.) (2002) A Era FHC: Um Balanço, São Paulo: Cultura Editores Associados LANDAU, G.D. (2002) 'The regulatory-normative framework in Brazil', Policy Papers on the Americas, Vol. XIII April, Study 2, Washington D.C.: Centre for Strategic and International Studies

LINHARES PIRES, J.C., F. Giambiagi \& A. F. Sales (2002) 'As perspectivas do setor eletrico após o racionamento', Revista do BNDES, 18, Dezembro, pp. 163-203

Ministério de Transportes (2000) Relatórios Trimestrais de Acompanhamento de Concessões, Brasília: Ministério de Transportes

SALGADO, L.H (2003) 'Agências regulatórias na experiência Brasileira: um panorama do atual desenho institucional' IPEA Texto para discussão, No. 941

SPILLER, P. \& Viana-Martorell, L. (1996) 'How should it be done? Electricity regulation in Argentina, Brazil, Uruguay and Chile', in R.G Gilbert and E.P. Kahn (eds.) International Comparisons of Electricity Regulation, Cambridge: Cambridge University Press, pp. 82-125

SPILLER, P. \& Cardilli, C. G. (1997) 'The frontier of telecommunications de-regulation: small countries leading the pack', Journal of Economic Perspectives, 11 (4), pp. 127-138

WELLS, J (1976) 'Underconsumption, market size and expenditure patterns in Brazil', Bulletin of the Society for Latin American Studies, No. 24 March

WERNECK, R. F (1986) 'Poupança estatal, divida externa e crise financeira do setor público', Pesquisa e

Planejamento Econômico, 16, No. 3 (Dezembro)

\section{Edmund Amann}

PROFESSOR OF ECONOMICS SCHOOL OF ECONOMICS, UNIVERSITY OF MANCHESTER, UK

Werner Baer 
Revista Direito GV, São Paulo, p. 267-281, 2005. Edição especial 1. 